\title{
Kalanchoe daigremontiana: Functional Properties and Histopathological Effects on Wistar Rats under Hyperglycemia-inducing Diet
}

\author{
Alfredo Madariaga-Navarrete', Eliazar Aquino-Torres', Raquel Cariño-Cortés², Roberto \\ Villagómez-lbarra ${ }^{3}$, Juan Ocampo-López ${ }^{4}$, Ashutosh Sharma ${ }^{5}$, Alma Delia Hernández-Fuentes ${ }^{6, *}$
}

\begin{abstract}
1'Área Académica de Ciencias Agrícolas y Forestales, Instituto de Ciencias Agropecuarias, Universidad Autónoma del Estado de Hidalgo. Tulancingo, Hidalgo, MEXICO.

${ }^{2}$ Instituto de Ciencias de la Salud. Universidad Autónoma del Estado de Hidalgo. Pachuca, Hidalgo, MEXICO.

${ }^{3}$ Área Académica de Química, Instituto de Ciencias Básicas e Ingeniería, Universidad Autónoma del Estado de Hidalgo. Pachuca, Hidalgo, MEXICO.

${ }^{4}$ Área Académica de Medicina Veterinaria, Instituto de Ciencias Agropecuarias, Universidad Autónoma del Estado de Hidalgo. Tulancingo, Hidalgo, MEXICO.

${ }^{5}$ Tecnologico de Monterrey, School of Engineering and Sciences, Epigmenio Gonzalez San Pablo, Querétaro. Qro, MEXICO.

${ }^{6}$ Área Académica de Ingeniería Agroindustrial, Instituto de Ciencias Agropecuarias, Universidad Autónoma del Estado de Hidalgo. Avenida Universidad Km, Exhacienda Aquetzalpa Tulancingo, Hidalgo, MEXICO.
\end{abstract}

\begin{abstract}
Introduction: Diabetes is a worldwide pandemic disease with an expensive way of control. Locals around the world have been used botanical extracts to reduce the effects of this deadly disease to improve the quality of life of the patients. Objectives: To evaluate the effects of crude extracts of the ethnobotanical species $K$. daigremontiana on a hyperglycemia rat model to support its antidiabetic use in traditional medicine. Materials and Methods: Crude leaves extract were daily administered per os to Wistar rats for six months. Hyperglycemic induction model was rich-sucrose diets. Six animals per group were used: i) standard diet, ii) sucrose-rich diet, iii) sucrose-rich diet + extract $(1 \mathrm{ml})$, iv) sucrose-rich diet + extract $(2 \mathrm{ml})$ and v) standard diet + extract $(2 \mathrm{ml})$. All animals were sacrificed and the liver prepared for histopathological analysis. Powdered leaves were functionally characterized and analyzed by Fourier Transform Infrared (FTIR) spectroscopy. Results: Treatment with $2 \mathrm{ml}$ of the crude extract caused the least tissue damage, compared to the control. A high antioxidant activity (DPPH: $111.14 \mu \mathrm{M}$ Trolox equivalents g-1 dry weight (DW); ABTS: $223.90 \mu \mathrm{M}$ Trolox equivalents g-1 DW) was observed. A content of $0.54 \mathrm{mg}$ ascorbic acid g-1 DW, total phenol content of 17.45 mg gallic acid g-1 DW and flavonoid content of $2.3 \mathrm{mg}$ equivalent quercetin g-1 DW were determined. No conclusive evidence on the molecules present in the extract was obtained by FTIR spectroscopy. Conclusion: The use of dosages of $2 \mathrm{ml}$ of crude extract of Kalanchoe daigremontiana reduces liver damage under high sucrose conditions.
\end{abstract}

Key words: Traditional medicine, Anti-hyperglycemic, Diabetes Sucrose-rich diet, Kalanchoe daigremontiana, Phytotherapy.

\section{INTRODUCTION}

Diabetes has become one of the greatest epidemics of the $21^{\text {st }}$ century. The World Health Organization (WHO) estimated that diabetes incidence has tripled since 1995 and today more than 347 million people worldwide live with diabetes. ${ }^{1}$ According to the International Diabetes Federation (IDF), ${ }^{2}$ the countries with the highest diabetes incidence are China, India, the United States, Brazil, Russia and Mexico (in that order). Diabetes is a chronic disease with complex etiology and severe consequences both for the patient and society. Therefore, a comprehensive, affordable and human treatment is urgently needed. One possible approach is the use of
Submission Date: 08-08-2019; Revision Date: 06-02-2020; Accepted Date: 01-03-2021

DOI: 10.5530/ijper.55.2.82 Correspondence:

Dr. Alma Delia Hernández-Fuentes Área Académica de Ingeniería Agroindustrial, Instituto de Ciencias Agropecuarias, Universidad Autónoma del Estado de Hidalgo. Avenida Universidad Km. $1 \mathrm{~s} / \mathrm{n}$. Exhacienda Aquetzalpa Tulancingo-43600, Hidalgo, MEXICO.

Phone no: +52-771-7172000 Email id: hfad@hotmail.com

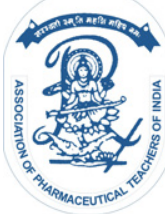

www.ijper.org 
extracts of Kalanchoe daigremontiana Raym.-Hamet and $\mathrm{H}$. Perrier (Crassulaceae). ${ }^{3}$ The use of this plant in traditional medicine is well known, especially in North and South America. ${ }^{4}$

According to the International Diabetes Federation (IDF), the countries with highest diabetes incidence are China, India, the United States, Brazil, Russia and Mexico (in that order). Mexico ranks eighth in diabetes prevalence. The country will occupy the sixth or seventh place by 2025, with 11.9 million Mexicans with diabetes. Since 2000, diabetes is the leading cause of death in Mexico, accounting for $17.2 \%$ of total mortality. ${ }^{1}$ The National Nutrition Survey 2012 showed that $9.17 \%$ of the adult population was diagnosed with diabetes, i.e. 6.4 million people.

In México, $15.78 \%$ of diabetes patients lack social security and almost two-thirds of them are treated by private medics. Among patients covered by social security, nearly $24 \%$ receive treatment in the Social Protection System of Health and the rest attend the Mexican Social Security Institute (IMSS). The direct cost of diabetes for 20-79 years-old patients ranges from 232 to 422 billion dollars per year worldwide. If diabetes incidence grows as predicted, by 2025 this cost will be 303-559 billion dollars. In Mexico, the total cost of diabetes grew from 2.97 billion Mexican pesos in 2003 to 8.84 billion in $2010 .^{5}$

Being diabetes a chronic disease with complex etiology and severe consequences both for the patient and society, a comprehensive, affordable and human treatment is urgently needed. One possible approach is the use of extracts of Kalanchoe daigremontiana Raym-Hamet and $\mathrm{H}$. Perrier (Crassulaceae) ${ }^{6-8}$

The use of this plant in traditional medicine is well known, especially in North and South America.9-13 While the use of medicinal plants was widespread two centuries ago, it fell into disuse with the advent of modern pharmacy. Nevertheless, the interest in herbal medicines as a therapeutic alternative has revived due in part to the inaccessibility to health services among poorer population, along with a lack of access to drugs and the high costs involved. Currently, many plant species are under study to identify and isolate substances for therapeutic use and to produce nutraceutical or functional products, to prevent diseases.

The use of medicinal plants is deeply rooted in Mexico. Specifically, ethno-botanical research has recorded about 300 species with hypoglycemic properties. This traditional use, however, is limited by the lack of knowledge on the active substance and its effects and on the therapeutic dose and by the likely occurrence of side effects and toxicity. The wide variations in preparation methods, administration routes and the physical properties of the drugs further complicate the safe and efficacious use of medicinal plants.

Kalanchoe daigremontiana is a perennial, glabrous herb, ${ }^{14}$ commonly known as "Mother-of-Thousands"; it reproduces by developing whole plantlets on leaves. ${ }^{15}$ Originally native to South Africa, India, China and Brazil, numerous Kalanchoe species are widely distributed in tropical and subtropical areas. ${ }^{16}$ Native to Madagascar, $K$. daigremontiana is considered a noxious invasive plant in arid zones. It is commonly found in disturbed sites of the semiarid northeastern region of Guanajuato and also in Querétaro and Hidalgo, Mexico (Figure 1).

Different types of secondary metabolites have been isolated from Kalanchoe spp. in recent decades. Among them are alkaloids; ${ }^{17,18}$ anthraquinones and bufadienolides ${ }^{19}$ carbazoles, coumarins and lactones; ${ }^{20,21}$ lignans, phenylnaphthalene, quassinoids and saponins; $;^{22,23}$ stivenes and terpenes; ${ }^{24-27}$ Antitumor, ${ }^{24}$ antihistaminic, anti-inflammatory, ${ }^{28}$ and immunomodulatory ${ }^{29,30}$ effects have been reported for some species of the genus. Flavonoid glycosides are vegetable pigments with antioxidant capacity and bufadienolides are cardioactive steroids whose efficacy against heart disease was already known to the ancient Egyptians. ${ }^{31}$

An aqueous preparation from $K$. pinnata L. (Crassulaceae) was reported to show a hypoglycemic effect, ${ }^{32}$ and a similar effect was found in an ethanol extract of the plant, observing decreased blood sugar levels and improvements in morphology and number of B cells in Langerhans islets. ${ }^{33}$

Various works have studied the number, properties and type of molecules involved in the therapeutic effects of Kalanchoe spp. This study is aimed to provide scientific support to the traditional use of $K$. daigremontiana as an antidiabetic, characterizing the functional properties
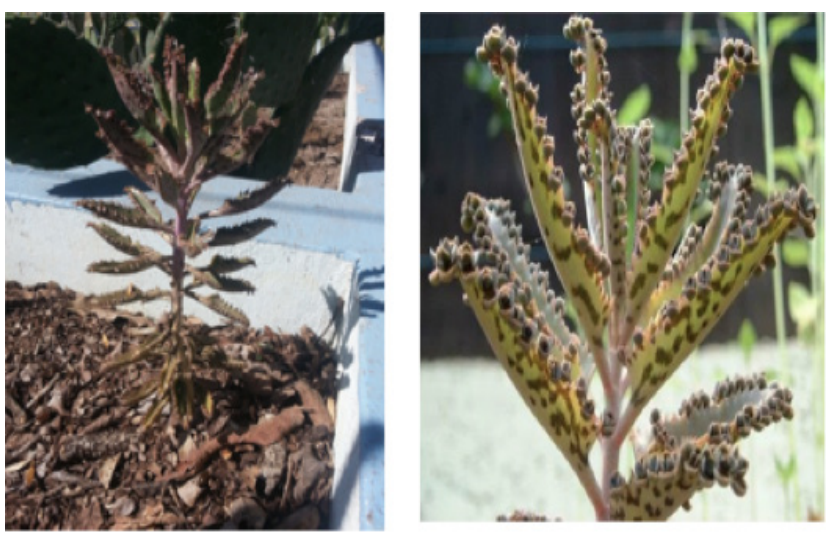

Figure 1: Kalanchoe daigremontiana specie.

Shrub type plant, from $20 \mathrm{~cm}$ to $50 \mathrm{~cm}$ high. Petiolate, triangular, oblonglanceolate leaves with serrated margin. From 1 to $3 \mathrm{~cm}$ wide by 4 to 5 long. Simple stems, erect, rounded, 1 to $2 \mathrm{~cm}$ thick. 
of powdered leaves, determining its composition by functional group analysis and assessing in vivo the biological activity (histopathological effects) of a crude $K$. daigremontiana extract on a hyperglycemia model.

\section{MATERIALS AND METHODS}

\section{Plant material collection and species identification}

$K$. daigremontiana specimens were collected (during March 2015) by Dr. Alma Delia Hernández-Fuentes in Ulapa de Melchor Ocampo, Tetepango, Hidalgo, in Central Mexico, at -99.167778 longitude, 20.142500 latitude (GPS coordinates). Traditionally, local people have used this plant species in their traditional healthcare system. Whole plants (roots, leaves and stems) were collected and prepared for the transportation. Species identification was performed in the laboratory of botany at the Institute of Biological Sciences of the Universidad Autónoma del Estado de Hidalgo. A voucher specimen representing the plant material was deposited in the herbarium of the Institute of Biological Sciences of the Universidad Autónoma del Estado de Hidalgo and the identification code 06 was assigned.

\section{Characterization of the functional properties of the leaves}

To characterize the functional properties of $K$. daigremontiana leaves, the following parameters were assessed: ascorbic acid content, total phenolic content, flavonoid content and antioxidant activity.

The ascorbic acid content was determined according to Klein and Perry, ${ }^{34}$ total phenol and flavonoid contents were determined after extraction with methanol, as described by Rosales et al. ${ }^{35}$ with slight modifications. Antioxidant activity was determined according to Brand-Williams et al. ${ }^{36}$ as the free radical 2,2-diphenyl1-picrylhydrazyl (DPPH) scavenging activity. The antioxidant capacity was determined by the Trolox equivalent method (TEAC) as described by Re et al. ${ }^{37}$

\section{Functional group analysis}

\section{Fourier Transform Infrared (FTIR) spectroscopic analysis}

For the FTIR studies, dried $K$. daigremontiana $(50 \mathrm{~g}$ ) of leaves were cut into small pieces and soaked in $250 \mathrm{ml}$ of reagent-grade methanol for seven days. The methanol solution was filtered and concentrated under vacuum using a rotary evaporator (BÜCHI R-210, Flawil, Germany). The functional groups in the methanol extract of $K$. daigremontiana were determined by FTIR spectroscopy (Perkin-Elmer GXFT-IR, Waltham, MA). An absorption spectrum was recorded in the range
4000-400 $\mathrm{cm}^{-1}$ at room temperature. The sample was prepared using the standard $\mathrm{KBr}$ pellet method.

\section{Biological activity \\ Preparation of the extract}

Harvested plants were rinsed three times with sterile distilled water and the leaves were collected. Leaves were dusted off, cleaned, allowed to dry in the shade and weighed. Leaves were macerated without any solvent (dry milled) in a commercial juice extractor (UNIWORL UJC-N50 model, Bell, CA) to obtain the extract. The crude extract was filtered through a Whatman grade 40-filtration paper. An average of 230 $\mathrm{ml}$ of filtered crude extract was obtained per every 500 $\mathrm{g}$ of plant leaves.

\section{Experimental animals}

Male Wistar albino rats weighing 190-200 g bred in the Vivarium of the Institute of Health Sciences, Universidad Autónoma del Estado de Hidalgo (Pachuca, Hidalgo, Mexico) were used in this study. The Bioethics Committee of the Institute of Health Sciences approved the research protocol and the identification code 202014 was assigned.

All animals were housed in polypropylene cages $(43 \times$ $27 \times 15 \mathrm{~cm}$ ); each cage lodged no more than six animals. The animals were kept in an isolation room at $17^{\circ} \mathrm{C}$, $30 \% \mathrm{RH}$, under a $12 \mathrm{~h}$ light/dark cycle. All animals were acclimatized for two weeks before experimental use. All guidelines established in the Mexican Official Norm (NOM-062-ZOO-1999) ${ }^{38}$ concerning the production, care and use of laboratory animals were followed, as well as the procedures for the Care and Use of Laboratory Animals. ${ }^{39}$

\section{Induction of hyperglycemia}

To induce experimental hyperglycemia, rats were fed with a sucrose-rich diet (SuRD). To this end, a standard pellet diet (Global Teklab ${ }^{\mathrm{TM}}$ food for rodents, 18\% protein, sterilizable) was supplemented with a $30 \%$ sucrose solution ( $300 \mathrm{~g}$ of pure sucrose in $1 \mathrm{~L}$ of sterile water); both components were allowed ad libitum.

\section{Experimental setup}

The animals were distributed into five groups as described below. K. daigremontiana extract was administered daily through an intra-gastric gavage to prevent degradation of active components. The animals were allowed water ad libitum and were fed with their respective diet for six months. Individual weight gain was evaluated during this period by recording individual rat weight once a week.

Rats were distributed as follows: Group I: Normal control. Animals were fed with standard pellet diet and 
sterilized water ad libitum. Group II: Negative control. Untreated, hyperglycemia-induced rats. Group III. Positive control. Animals were fed with standard diet +2 $\mathrm{ml}$ of $K$. daigremontiana extract (preventive effect). Group IV: Animals fed with SuRD $+1 \mathrm{ml}$ of $K$. daigremontiana extract (therapeutic effect). Group V: Animals fed with $\mathrm{SuRD}+2 \mathrm{ml}$ of $K$. daigremontiana extract (therapeutic effect).

After six months, when significant differences in weight gain among groups were evident, the animals were humanely sacrificed and the liver was retrieved for macroscopic examination and histological studies.

\section{Histopathology}

Liver samples from each group were fixed in 3.8\% formaldehyde phosphate buffered aqueous solution for at least $24 \mathrm{hr}$. Then, samples were included in paraffin inclusion and an automated tissue processor (Microm, model TP1020, Thermo Fisher Scientific ${ }^{\text {TM}}$ ) was used. Four-micrometer-thick slices were obtained in a manual microtome (Leica ${ }^{\mathrm{TM}}$, model 2125RT, Nussloch, Germany) and stained with hematoxylin-eosin (HE). ${ }^{40}$ Histological preparations were analyzed with a lightfield microscope (Olympus ${ }^{\mathrm{TM}}$, model BX-41, Waltham, $\mathrm{MA})$. Images were taken with a digital camera (Evolution VF TM, Media Cybernetics, Rockville, MD) and processed with the software Image Pro Express v.6.0 (Media Cybernetics).

\section{Statistical analysis}

The results were analyzed by one-way ANOVA and a Tukey-Kramer post hoc test. Differences between groups were regarded as significant when $P<0.05$.

\section{RESULTS}

\section{Functional characterization of leaves}

$K$. daigremontiana powdered leaves showed a content of $0.54 \mathrm{mg}$ of ascorbic acid/ DW, a total phenol content of $17.45 \mathrm{mg}$ gallic acid/g DW and a flavonoid content of $2.3 \mathrm{mg}$ of equivalent quercetin/g DW. Concerning antioxidant activity, $111.14 \mu \mathrm{M}$ Trolox/g DW and 223.90 $\mu \mathrm{M}$ Trolox/g were determined by DPPH (2,2-diphenyl1-picryl-hydrazyl-hydrate) and ABTS ((2,2'-azino-bis(3ethylbenzothiazoline-6-sulfonic acid), respectively. Results are summarized in Table 1.

\section{Functional group analysis}

FTIR spectroscopy was used to identify the functional groups in a $K$. daigremontiana methanol extract. A representative spectrum is shown in Figure 2. The presence of $-\mathrm{OH}$ vibration strain bands from different chemical environments was evident in the 3600-3100 $\mathrm{cm}^{-1}$ interval. A prominent band observed at $3424 \mathrm{~cm}^{-1}$ corresponded to hydroxyl groups. Bands in the 2973$2917 \mathrm{~cm}^{-1}$ interval are associated with $\mathrm{C}-\mathrm{H}$ stretching vibrations from $\mathrm{CH}_{2}$ and $\mathrm{CH}_{3}$. The band at $1625 \mathrm{~cm}^{-1}$ can be attributed to amines. The intense band at 1051 $\mathrm{cm}^{-1}$ was assigned to $\mathrm{C}-\mathrm{O}$ bond stretching vibration. ${ }^{41}$ The band from 831 to $770 \mathrm{~cm}^{-1}$ represents the $\mathrm{C}-\mathrm{H}$ banding region, out of the plane, with signals of low intensities. Results are summarized in Table 2.

\section{Biological activity}

\section{Hyperglycemia induction}

Table 3 summarizes the total weight gain in rats after six months of a sucrose-rich diet. Statistically significant differences in weight gain were observed between experimental groups. Positive control (animals fed with SuRD) averaged $599 \mathrm{~g}$, while negative control (animals under standard diet) averaged $548 \mathrm{~g}$. These results suggest that the method to induce hyperglycemia and its relation with overweight are useful for this study.

Animals fed with standard diet and treated with $2 \mathrm{ml}$ of crude $K$. daigremontiana showed the lowest mean weight. This could indicate the effectiveness of the crude extract for preventive purposes. No significant differences in final mean weight were observed between animals fed with SuRD and treated with 1 or $2 \mathrm{ml}$ of the crude extract.

\section{Histopathology}

The results are summarized in Table 4 and Figure 3. Animals in the negative control group, fed with SuRD with no extract supplement (Group I) showed hepatocytes with a significant number of vacuoles and many hepatocytes exhibited hollow spaces (Figure 3A) [moderate damage, Table 3].

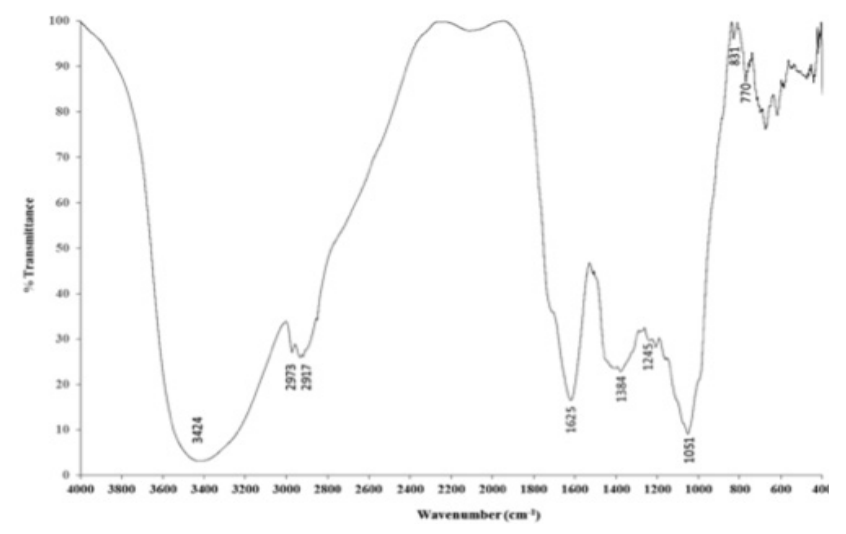

Figure 2: Fourier transform infrared spectrum of methanolic leave extract of Kalanchoe daigremeontiana. 

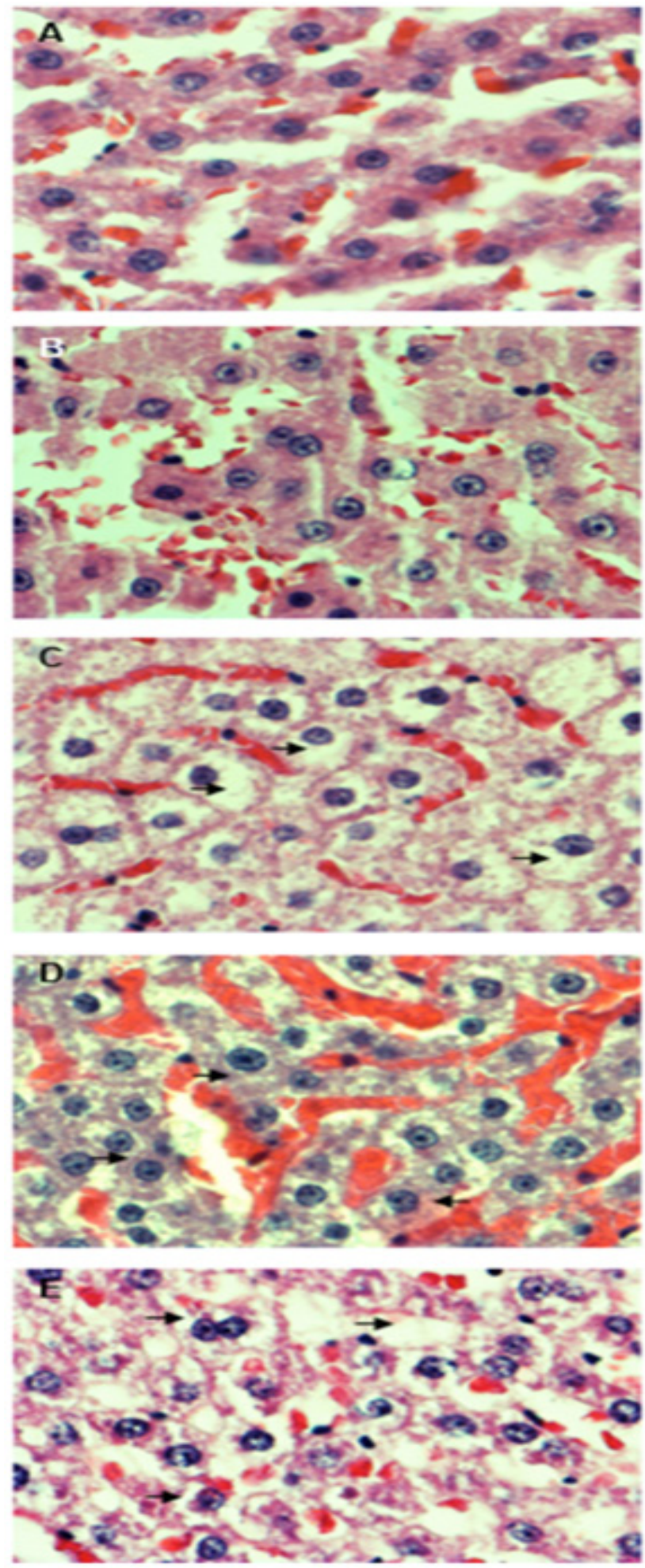

Figure 3: Histopathological changes in Wistar rats liver under a high sucrose diet treated with Kalanchoe daigremontianda crude extracts.

3A. Negative control (sugar-rich diet). The hepatocytes are observed with large empty spaces in their cytoplasm and several of them have lost their characteristic polyhedral shape (arrows). 3E. Positive control (standard diet). Changes in hepatocytes are minimal. 3B. SD $+2 \mathrm{~mL}$ (standard diet $+2 \mathrm{~mL}$ of extract). Changes in hepatocytes are minimal. 3 C. SuRD $+1 \mathrm{~mL}$ (sugar-rich diet $+1 \mathrm{~mL}$ of extract). The presence of numerous vacuoles (arrows) in the cytoplasm of hepatocytes is observed. $2 \mathrm{D}$. SuRD $+2 \mathrm{~mL}$ (sugar-rich diet $+2 \mathrm{~mL}$ of extract). Normal tissue architecture. There are large numbers of vacuoles in hepatocytes.
Table 1: Content of carotenoids, ascorbic acid, total phenols, total flavonoids and antioxidant activity by by DPPH (2,2-diphenyl-1-picryl-hydrazyl-hydrate) and ABTS ((2,2'-azino-bis(3-ethylbenzothiazoline-6sulfonic acid) in Kalanchoe daigremontiana leaves.

\begin{tabular}{|c|c|}
\hline Function & \multicolumn{1}{|c|}{ Values } \\
\hline Red carotenoids $\left(\mathrm{mg} \mathrm{g}^{-1} \mathrm{DW}\right)$ & $0.39 \pm 0.011$ \\
\hline Yellow carotenoids $\left(\mathrm{mg} \mathrm{g}^{-1} \mathrm{DW}\right)$ & $0.46 \pm 0.010$ \\
\hline Total carotenoids $\left(\mathrm{mg} \mathrm{g}^{-1} \mathrm{DW}\right)$ & $0.85 \pm 0.014$ \\
\hline Ascorbic acid $\left(\mathrm{mg} \mathrm{g}^{-1} \mathrm{DW}\right)$ & $0.54 \pm 0.21$ \\
\hline Total phenols $\left(\mathrm{mg} \mathrm{GAE} \mathrm{g}^{-1} \mathrm{DW}\right)$ & $17.35 \pm 0.12$ \\
\hline Flavonoids total $\left(\mathrm{mg} \mathrm{QE} \mathrm{g}^{-1} \mathrm{DW}\right)$ & $21.40 \pm 1.50$ \\
\hline DPPH $\left(\mu \mathrm{M} \mathrm{TE} \mathrm{g}{ }^{-1} \mathrm{DW}\right)$ & $110.85 \pm 0.36$ \\
\hline ABTS $\left(\mu \mathrm{M} \mathrm{TE} \mathrm{g}{ }^{-1} \mathrm{DW}\right)$ & $222.43 \pm 3.43$ \\
\hline
\end{tabular}

\section{Table 2: Major functional groups observed in the Fourier transform infrared spectra of methanolic leave extract.}

\begin{tabular}{|c|c|c|}
\hline $\begin{array}{c}\text { IR spectral } \\
\left.\text { values } \mathbf{( c m}^{-1}\right)\end{array}$ & $\begin{array}{c}\text { Bond and } \\
\text { functional groups }\end{array}$ & $\begin{array}{c}\text { Probable } \\
\text { phytochemicals }\end{array}$ \\
\hline 3424 & O-H & Polyphenols, tannins \\
\hline 2973 & $\begin{array}{c}\left(\mathrm{CH}_{3}, \mathrm{CH}_{2}, \mathrm{CH}\right) \\
\text { alkanes }\end{array}$ & $\begin{array}{c}\text { Flavonoids and } \\
\text { polyphenols }\end{array}$ \\
\hline 1625 & $\begin{array}{c}\left(\mathrm{NH}_{2} \text { scissoring }\right) \\
\text { amines }\end{array}$ & $\begin{array}{c}\text { Alkaloids, flavonoids } \\
\text { and polyphenols }\end{array}$ \\
\hline 1384 & $\begin{array}{c}\left(\mathrm{CH}_{3}, \mathrm{CH}_{2}\right) \text { alkanes, } \\
\text { O-H bending }\end{array}$ & $\begin{array}{c}\text { Flavonoids, tannins } \\
\text { and polyphenols }\end{array}$ \\
\hline 1245 & $\begin{array}{c}\mathrm{O}-\mathrm{C} \text { carboxylic acid } \\
\text { derivates }\end{array}$ & $\begin{array}{c}\text { Flavonoids, tannins } \\
\text { and carboxylic acid } \\
\text { derivates }\end{array}$ \\
\hline 1051 & $\begin{array}{c}\mathrm{O}-\mathrm{H} \text { alcohols and } \\
\text { phenols }\end{array}$ & $\begin{array}{c}\text { Flavonoids, } \\
\text { polyphenols }\end{array}$ \\
\hline $831-770$ & $=\mathrm{C}-\mathrm{H}$ & $\begin{array}{c}\text { Flavonoids, tannins } \\
\text { and polyphenols }\end{array}$ \\
\hline & &
\end{tabular}

Animals fed with standard diet (positive control) showed normal liver tissue architecture, with hepatocytes exhibiting clear vacuoles and some albuminous degeneration (due to sample collection time) (Figure 3E).

No differences were observed in animals fed with standard diet supplemented with $2 \mathrm{ml}$ of the crude extract (preventive effect, Group III, Figure 3B) with respect to normal controls.

Animals fed with SuRD supplemented with $1 \mathrm{ml}$ of crude extract (curative effect, group IV) showed normal liver tissue architecture. However, the cytoplasm of some hepatocytes exhibited abundant vacuoles, while other cells had a normal appearance, in variable proportions (Figure $3 \mathrm{C}$ ).

Animals in group V (curative effect), fed with SuRD and treated with $2 \mathrm{ml}$ of crude extract showed a normal liver 
Table 3: Total weight gain after six months of sucrose-rich diet in rats treated with crude Kalanchoe daigremontiana extract.

\begin{tabular}{|c|c|}
\hline Treatment & Average weight $\mathbf{( g )}$ \\
\hline Negative control (sugar-rich diet) & $599^{\mathrm{a}}$ \\
\hline Normal control (standard diet) & $548^{\mathrm{b}}$ \\
\hline $\begin{array}{c}\mathrm{SD}+2 \mathrm{ml} \text { (standard diet }+2 \mathrm{ml} \text { of } \\
\text { extract) }\end{array}$ & $418^{\mathrm{c}}$ \\
\hline $\begin{array}{c}\text { SuRD }+1 \mathrm{ml} \text { (sugar-rich diet }+1 \mathrm{ml} \text { of } \\
\text { extract) }\end{array}$ & $565^{\mathrm{d}}$ \\
\hline $\begin{array}{c}\text { SuRD }+2 \mathrm{ml} \text { (sugar-rich diet }+2 \mathrm{ml} \text { of } \\
\text { extract) }\end{array}$ & $596^{\mathrm{d}}$ \\
\hline
\end{tabular}

Letters indicate significant differences (with $\alpha=0.05$, Tukey-Kramer test)

Table 4: Histological changes in liver tissues.

\begin{tabular}{|c|c|c|c|}
\hline Groups & $\begin{array}{c}\text { Liver } \\
\text { damage }\end{array}$ & Vacuolation & hepatocytes \\
\hline $\begin{array}{c}\text { I. Negative control } \\
\text { (sugar-rich diet) }\end{array}$ & $@ @ ~$ & +++ & $\# \#$ \\
\hline $\begin{array}{c}\text { II. Normal control } \\
\text { (standard diet) }\end{array}$ & 0 & + & $\#$ \\
\hline $\begin{array}{c}\text { III. SD }+2 \mathrm{ml} \\
\text { (standard diet }+2 \\
\text { ml of extract) }\end{array}$ & 0 & + & $\#$ \\
\hline $\begin{array}{c}\text { IV. SuRD }+1 \text { ml } \\
\text { (sugar-rich diet }+1 \\
\text { ml of extract) }\end{array}$ & 0 & +++ & $\#$ \\
\hline $\begin{array}{c}\text { V. SuRD }+2 \mathrm{ml} \\
\text { (sugar-rich diet }+2 \\
\text { ml of extract) }\end{array}$ & 0 & +++ & $\# \#$ \\
\hline
\end{tabular}

Liver tissue damage: $0=$ No damage. @ = Mild damage. @ @ = Moderate damage. @@@ = Marked damage. Vacuolation: + = normal presence of vacuoles. $++=$ Moderate high presence of vacuoles. $+++=$ Significant high presence of vacuoles. Hepatocytes: \# Normal appearance. \#\# = Moderate damage. $\# \# \#=$ Marked damage.

tissue architecture, but several hepatocytes exhibited vacuoles, while other cells had a normal appearance (Figure 3D).

\section{DISCUSSION}

Diabetes is becoming a global pandemic and coping with it requires inexpensive and effective means to improve the patients' quality of life. This goal could be achieved by using plant extracts. Several protocols and techniques have been developed to determine the usefulness and mechanisms of action of herbal remedies. The phytochemical characterization of the extract is a mandatory step, followed by testing the effectiveness of the extract in vivo. Thus, a reliable biological model of the disease, diabetes in this case, is required. One of the most commonly reported methods for diabetes induction in rats involves the use of streptozotocin
(STZ). The effects of STZ are variable and usually are observed after a period of 15 days- 8 weeks. ${ }^{42-46}$

In contrast, the effects of SuRD administration seem to be closer to the pathogenesis of the disease and that is why it was used in this study. SuRD administration is a reliable method to produce metabolic disorders. ${ }^{47}$ The results herein reported are similar to those found by Long et al. ${ }^{48}$ that SuRD induced mild glucose intolerance after two months of treatment followed by "temporally no symptom phase (after three months) and then produced significant metabolic abnormality." Accordingly, we expected the in vivo studies to last about three months. Rat body weight varied significantly during this period, but it was until month 6 that overweight was observed. The slow progression of this metabolic disorder is also representative of the natural process of the disease in humans, so it is likely that the effect of $K$. daigremontiana extract is also more representative.

The content of carotenoids in the leaves of Kalanchoe daigremontiana was lower than that reported by SantiagoSaenz et al..$^{49}$ in purslane (Portulaca oleracea L.), quelite ash (Chenopodium berlandieri L.) and quintonil (Amaranthus bybridus L.). In this regard, it is mentioned that carotenes protect the cells and tissues of highly oxidizing radicals and singlet oxygen, through their antioxidant activity Cosme et al. ${ }^{50}$ However, the content of ascorbic acid was higher than that reported for quality ash and quintonil. This vitamin is a powerful antioxidant useful for the elimination of free radicals from the human body. In nutritional terms, the recommended minimum requirement of vitamin $\mathrm{C}$ for an adult is $60 \mathrm{mg} .{ }^{.1} \mathrm{In}$ relation to the content of total phenols and flavonoids, this content was higher in $K$. daigremontiana than reports by Santiago-Saenz et al. ${ }^{49}$ This is important because total phenols and flavonoids are useful to treat diseases related to inflammatory processes and cardiovascular disorders due to the activity they exert on the human circulatory system. ${ }^{52}$ The ABTS test showed a higher value than that obtained by DPPH, which indicates that the ABTS test is better for matrices such as fruits, vegetables and oils.

Obesity is a complex metabolic disorder, associated to diseases such as cirrhosis, non-alcoholic fatty liver disease and diabetes Type 2. In humans and rodents, obesity promotes hepatic steatosis and inflammation. ${ }^{53}$ Since obesity is characterized by an excessive body fat accumulation, diabetes type 2 and obesity are both associated with hypertension and hyperlipidemia. ${ }^{54}$ In our experiment, after six months of SuRD administration, the negative control group showed the highest mean weight, indicating overweight and possibly a propensity to diabetes. 
Our results agree with those reported by Kurup and Mini. ${ }^{55}$ Histopathological study showed the effectiveness of an extract from Averrhoa bilimbi L. (Oxalidaceae) to efficiently prevent oxidative damage in hepatocytes without affecting the cellular structural integrity in STZ-induced diabetic rats, possibly by activating tissue antioxidants. Soliman et al. ${ }^{56}$ reported that extracts from Origanum majorana L. (Lamiaceae) reverted histopathological changes in liver and kidney by decreasing lipid accumulation and increasing the regeneration of hepatic parenchyma, restoring normal renal architecture and removing fat droplets. Hazarika $e t$ al..$^{57}$ observed lipid droplets in the liver and an increase in adipocyte size in Wistar albino rats fed with a highcarbohydrate diet, concluding that such diet caused ultrastructural abnormalities. In our experiment, normal controls presented normal liver tissue architecture, while negative controls showed numerous vacuolated hepatocytes. This is in agreement with the study by Kurup and Mini ${ }^{55}$ cited above.

Histopathological damage in pancreas, liver and kidney secondary to diabetes improved after treatment with hydroalcoholic leaf extract from Citrullus colocynth L. (Cucurbitaceae) in STZ-induced diabetic rats. It was also concluded that $C$. colocynthis leaf extracts might have a protective effect on liver, kidney and pancreas.

Sirovina et al..$^{58}$ reported that administering naringenin (a flavonoid found in grapefruit, orange and tomato fruits) resulted in a significant decrease in lipid peroxidation in liver and kidney tissue, as well as in a reduced number of vacuolated liver cells and in the degree of vacuolization. Abdelaziz and $\mathrm{Ali}^{59}$ reported the protective effect of an aqueous suspension of Phoenix dactylifera L. (Araceae) seeds against chemically induced hepatic injury in rats. Liver histopathologic examination showed that $P$. dactylifera seeds decrease the incidence of liver lesions (including vacuolization and fibroblast proliferation); additionally, Gupta et al. ${ }^{60}$ demonstrated by liver histopathological examination that pioglitazone induced pathological liver damage. Further studies on liver tissues support its significant hepatoprotective activity on acetaminophen-induced hepatotoxicity.

Our results are in agreement with those reported by Sipal et al..$^{61}$ where diabetic rats treated with olmesertan exhibited regular hepatocyte plates. According to Bansal et al. ${ }^{62}$ a flavonoid from Pilea micropbylla (L.) Liebm. (Urticaceae) preserved islet architecture and prevented hepatocyte hypertrophy.

The biological activity of $K$. daigremontiana extract can be explained by its functional characterization. Yuliani et al. ${ }^{33}$ reported oxidative stress to play a key role in the pathogenesis of diabetes mellitus type
2. Supplementation with curcuminoids (natural polyphenols) was reported to exert an antioxidant effect in diabetic individuals and points to the need to investigate the impact of these antioxidant effects on diabetes and its complications. According to Yuliani, hyperglycemia is characterized by an increase in oxidative stress, which leads to an insufficiency in insulin secretion. We suggest that the reduction in liver cellular damage by $K$. daigremontiana extract is related to the antioxidant effect of constituents like quercetin (herein found in $K$. daigremontiana leaves). This agrees with the results reported by Iskender $e t$ al. ${ }^{63}$ that hesperidin and quercetin increased oxidative stress, while SIRT1 (NADdependent sirtuin-1 deacetylase) levels decreased in a STZ-induced diabetes experimental model. Almogbel and Rasheed ${ }^{64}$ suggested an association between protein oxidation and diabetes progression. They concluded that protein-mediated oxidative stress could be useful when evaluating diabetes progression in human patients. On the other hand, Ganjifrockwala et al. ${ }^{65}$ concluded that early management with an antioxidant-rich diet and lifestyle changes would help diabetes mellitus type 2 patients to overcome the debilitating complications of the disease.

The proposed model to assess in vivo the capacity of $K$. daigremontiana crude extract to reduce the effects of a sucrose-rich diet (diabetes promoter) could not be compared with other models, since no comparable experiments were found in the literature.

\section{CONCLUSION}

Considering that the administration of $2 \mathrm{ml}$ of $K$. daigremontiana crude extract to SuRD-fed rats decreased hepatic damage with respect to untreated controls and considering that functional analysis showed a high antioxidant activity in the extract which could be related to its biological activity, our findings provide a scientific rationale for the use of $K$. daigremontiana leaf extracts as a promising agent to prevent liver injury in diabetes. This contributes to validate the traditional use of $K$. daigremontiana as an antidiabetic. To the best of our knowledge, there are no reports in the literature on scientific confirmation of the traditional use of Kalanchoe daigremontiana in the recovery of hepatic damage caused by high sugar consumption. These are promising albeit preliminary results, meriting further studies.

\section{ACKNOWLEDGEMENT}

The senior author thanks Secretaría de Educación Pública, Mexico, for funding this research through the grant number UAEH-PTC-7001. Also, funding from 
the BioTech Innovation laboratories and the work of the research assistants Nallely Trejo and Santiago Cruz are fully appreciated.

\section{CONFLICT OF INTEREST}

The authors declare that they have no competing interests.

\section{ABBREVIATIONS}

SD: Standar diet; SuRD: Sugar rich diet.

\section{REFERENCES}

1. World Health Organization. Global report on diabetes. 2016;88. [Updated 2020 Feb 14; cited 2017 Aug 10]. Available from: http://www.who.int/diabetes/ publications/grd-2016/en/

2. International Diabetes Federation. 2018. [Updated 2020 Mar 14; cited 2018 Sep 18] Available from http://www.idf.org

3. Kamgang R, Mboumi RY, Fondjo MAF, Tagne GPR, Mengue N, Yonkeu $\mathrm{JN}$. Antihyperglycaemic potential of the water-ethanol extract of Kalanchoe crenata (Crassulaceae). J of Nat Med. 2008;62(1):34-40.

4. García-Hernández KY, Vibrans H, Rivas-Guevara V, Aguilar-Contreras A. This plant treats that illness? The hot-cold system and therapeutic procedures mediate medicinal plant use in San Miguel Tulancingo, Oaxaca, Mexico. $J$ Ethnopharmacol. 2015;163:12-30.

5. International Diabetes Federation. 2020. [Updated 2020 Mar 14; cited 11 Aug. 2017]. Available from: https://www.diabetesatlas.org/en/

6. Gugliucci A, Menini T. The botanical extracts of Achyrocline satureoides and Ilex paraguariensis prevent methylglyoxal-induced inhibition of plasminogen and antithrombin III. Life Sci. 2002;72(3):279-92.

7. Beecher GR. Proanthocyanidins: Biological activities associated with human health. Pharm Biol. 2004;42(Sup 1):2-20.

8. Halat KM, Dennehy CE. Botanicals and dietary supplements in diabetic peripheral neuropathy. J Am Board Fam Med. 2003;16(1):47-57.

9. Garcia-Carrancá A. Mexican medicinal plants used for cancer treatment: Pharmacological, phytochemical and ethnobotanical studies. J Ethnopharmacol. 2011;133(3):945-72.

10. Alcantara DS, López ML, Garcia-Martin A, Pozo D. Iron oxide nanoparticles as magnetic relaxation switching (MRSw) sensors: Current applications in nanomedicine. Nanomedicine. 2016;12(5):1253-62.

11. Alonso-Castro JA, Villarreal ML, Salazar-Olivo LA, Gomez-Sanchez M, Dominguez F, Garcia-Carranca A. Mexican medicinal plants used for cancer treatment: Pharmacological, phytochemical and ethnobotanical studies. J Ethnopharmacol. 2011;133(3):945-72.

12. Heinrich MA, Ankli B, Frei C, Weimann A, Sticher O. Medicinal plants in Mexico: Healers' consensus and cultural importance. Social Sci Medicine. 1998;47(11):1859-71.

13. Ankli A, Sticher $O$, Heinrich M. Yucatec Maya medicinal plants versus nonmedicinal plants: Indigenous characterization and selection. Hum Ecol. 1999;27(4):557-80.

14. Nahar K, Khan MGU, Rahman MS, Hasan CM, Rashid MA. Secondary metabolites from Bryophyllum daigremontianum. Dhaka Univ J Pharm Sci. 2008;1999(7):141-4.

15. Garcés H, Sinha N. The 'mother of thousands' (Kalanchoe daigremontiana): A plant model for asexual reproduction and CAM studies. Cold Spring Harb Protoc. 2009;10-7.

16. Cárdenas GC. Encuentros UMA. 2017. [Updated 2020 Mar 14; cited 11 Aug. 2017]. Available from http://www.encuentros.uma.es/encuentros $124 /$ articulos124.pdf

17. Kamgang R, Mboumi RY, Fondjo MAF, Tagne GPR, N'dille M, Yonkeu JN. Antihyperglycaemic potential of the water-ethanol extract of Kalanchoe crenata (Crassulaceae). J Nat Med. 2008;(62):34-40.
18. Stevens JF, Thart $\mathrm{HCH}$, Vanham JET, Elema M, Vandenent M, Wildeboer JH, et al. Distribution of alkaloids and tannins in the Crassulaceae. Biochem Syst Ecol. 1995;23(2):157-65.

19. Patil SB, Dongare VR, Kulkarni CR, Joglekar MM, Arvindekar AU. Antidiabetic activity of Kalanchoe pinnata in streptozotocin-induced diabetic rats by glucose independent insulin secretagogue action. Pharm Biol. 2013;(51):1411-8.

20. Sarkar RC, Mondal R, Bera S, Chakraborty R, Barik P, Roy A, et al. Antimicrobial properties of Kalanchoe blossfeldiana: A focus on drug resistance with particular reference to quorum sensing-mediated bacterial biofilm formation. J Pharm Pharmacol. 2015;67(7):951-62.

21. Schmidt TL, Beliveau BJ, Uca YO, Theilmann MF, DaCruz CT, Wu A, et al. Scalable amplification of strand subsets from chip-synthesized oligonucleotide libraries. Nat Commun. 2015;6(1):1-7.

22. Abhijit R. Phytochemical screening and in-vitro evaluation of antioxidant, cytotoxicity, antifungal activities of Kalanchoe pinnata (L). J of Sci Arts. 2015;15(4):343-50.

23. Okwu DE, Uchenna NF. Exotic multi-faceted medicinal plants of drugs and pharmaceutical industries. African Journal of Biotechnology. 2009;8(2):727182.

24. Hsieh YJ, Huang HS, Leu YLK, Peng KC, Chang CJ, Chang MY. Anticancer activity of Kalanchoe tubiflora extract against human lung cancer cells in vitro and in vivo. Environ Toxicol. 2016;31(11):1663-73.

25. Manan M, Hussain L, ljaz H, Qadir MI. Antimicrobial activity of Kalanchoe laciniata. Pak J Pharm Sci. 2016;29(4):1321-4.

26. Mora-Pérez A, Hernández-Medel ND. Anticonvulsant activity of methanol extract from Kalanchoe pinnata Lam. stems and roots in mice: A comparison to diazepam. Neurologia. 2016;31(3):161-8.

27. Rajsekhar PB, Bharani RSA, Ramachandran KJ, Vardhini A. A comparative study on the extracts of Kalanchoe pinnata (Linn) Pers. using chromatographic techniques. Int J Pharm Sci Res. 2016;7(1):345-8.

28. Chibli LA, Rodrigues CM, Gasparetto NC, Pinto RL, Fabri E, Scio MS, et al. Anti-inflammatory effects of Bryophyllum pinnatum (Lam.) Oken ethanol extract in acute and chronic cutaneous inflammation. J Ethnopharmacol. 2014;154(2):330-8.

29. Cruz EA, Da-Silva MF, Muzitano PMR, Silva SS, Costa B, Rossi-Bergmann B. Immunomodulatory pretreatment with Kalanchoe pinnata extract and its quercitrin flavonoid effectively protects mice against fatal anaphylactic shock. Int Immunopharmacol. 2008;8(2):1616-21.

30. Ibrahim TJ, Cunha K, Madi MB, DaFonseca SS, Costa A, Koatz VLG. Immunomodulatory and anti-inflammatory effects of Kalanchoe brasiliensis. Int Immunopharmacol. 2002;2(7):875-83.

31. Cárdenas GC. Encuentros UMA. 2017. [Updated 2020 Mar 14; cited 11 Aug. 2017]. Available from http://www.encuentros.uma.es/encuentros124/ articulos124.pdf

32. Menon N, Sparks J, Omoruyi F. Hypoglycemic and hypocholesterolemic activities of the aqueous preparation of Kalanchoe pinnata leaves in streptozotocin-induced diabetic rats. Asian Pac J Trop Biomed. 2015;5(1):3-9.

33. Yuliani T, Dewijanti ID, Banjarnahor SDS. Antidiabetic activity of ethanolic extracts of Kalanchoe pinnata leaves in alloxan induced hyperglycemic rats. Indonesian J Pharmacy. 2016;27(3):139-44.

34. Klein BP, Perry AK. Ascorbic acid and vitamin A activity in selected vegetables from different geographical areas of the United States. J Food Sci. 1982;(47):941-5.

35. Rosales MA, Cervilla LM, Sánchez-Rodríguez E, Rubio MDM, Blasco B, Ríos $\mathrm{JJ}$, et al. The effect of environmental conditions on nutritional quality of cherry tomato fruits: Evaluation of two experimental mediterranean greenhouses. J Sci Food Agric. 2011;91(1):152-62.

36. Brand-Williams W, Cuvelier ME, Berset C. Use of a free radical method to evaluate antioxidant activity. Lebenson Wiss Technol. 1995;28(1):25-30.

37. Ree R, Pellegrini N, Proteggente A, Pannala A, Yang M, Rice-Evans C. Antioxidant activity applying an improved ABTS radical cation decolorization assay. Free Radic Biol Med. 1999;26(9):1231-7.

38. Mexican Official Norm NOM-062-ZOO-1999. 2017. [Updated 2020 feb 14: cited 2017 Aug 10] Available from: https://www.gob.mx/senasica/documentos/ nom-062-zoo-1999

39. Hernández 2017. Icsa noticias. 2017. [Updated 2020 Feb. 16; cited 2017 Aug 19. Available from: https://www.uaeh.edu.mx/campus/icsa/noticias/2/ docs/2013/2/comite_etico_del_uso_de_imales_de_laboratorio.pdf 
40. Prophet E. Métodos histotecnológicos. $1^{\text {st }}$ Edition. Washington: American Registry of Pathology. 1995.

41. Socrates G. Infrared and Raman characteristic group frequencies: Tables and charts. $3^{\text {rd }}$ edition. USA. 2004.

42. Sharifzadeh MA, Ranjbar A, Hosseini A, Khanavi M. The Effect of Green Tea Extract on Oxidative Stress and Spatial Learning in Streptozotocin-diabetic Rats. Iran J Pharm Res. 2017;16(1):201-9.

43. Rocha IRC, Ciena AP, Rosa DO, Martins A, Chacur V. Photobiostimulation reverses allodynia and peripheral nerve damage in streptozotocin-induced type 1 diabetes. Lasers Med Sci. 2017;32(3):495-501.

44. Ahangarpour A, Heidari H, Oroojan AA, Mirzavandi F, Esfehani K, Mohammadi ZD. Antidiabetic, hypolipidemic and hepatoprotective effects of Arctium lappa root's hydro-alcoholic extract on nicotinamide-streptozotocin induced type 2 model of diabetes in male mice. Avicenna J Phytomed. 2017;7(2):169-79.

45. Abu SAM, Sharaf HH, Awad AY, El-Kotby HM, Fahmy EM. Comparative study for two methods for induction of diabetes in rats using streptozotocin. Diabet Med. 2017;34:45.

46. Nath S, Ghosh SK, Choudhury Y. A murine model of type 2 diabetes mellitus developed using a combination of high-fat diet and multiple low doses of streptozotocin treatment mimic the metabolic characteristics of type 2 diabetes mellitus in humans. J Pharmacol Toxicol Methods. 2017;84:20-30.

47. Balakumar M, Raji L, Prabh D, Sathishkumar C, Prabu P, Mohan V, et al. High-fructose diet is as detrimental as high-fat diet in the induction of insulin resistance and diabetes mediated by hepatic/pancreatic endoplasmic reticulum (ER) stress. Mol Cell Biochem. 2016;423(1):93-104.

48. Long Z, Zhang XS, Sun QG, Liu YN, Liao $\mathrm{H}, \mathrm{Wu} X$, et al. Evolution of metabolic disorder in rats fed high sucrose or high-fat diet: Focus on redox state and mitochondrial function. Gen Comp Endocrinol. 2017;242:92-100.

49. Santiago-Sáenz YO, Hernández-Fuentes AD, Monroy-Torres R, CariñoCortés R, Jiménez-Alvarado R. Physicochemical, nutritional and antioxidant characterization of three vegetables (Amaranthus hybridus L., Chenopodium berlandieri L., Portulaca oleraceae L.), as potential sources of phytochemicals and bioactive compounds. J Food Meas and Charact. 2018;12(4):1-10.

50. Cosme M, Franken P, Mewis I, Baldermann S, Wurst S. Arbuscular mycorrhizal fungi affect glucosinolate and mineral element composition in leaves of Moringa oleifera. Mycorrhiza. 2014;24(7):565-70.

51. Guzmán-Maldonado SH, Zamarripa-Colmenares A, Hernández-Duran LG. Calidad nutrimental y nutracéutica de hoja de moringa proveniente de árboles de diferente altura. Revista Mexicana De Ciencias Agrícolas. 2015;6(2):31730 .

52. Tattini M, Guidi L, Morassi-Bonzi L, Pinelli P, Remorini D, Degl'Innocenti E, et al. On the role of flavonoids in the integrated mechanisms of response of Ligustrum vulgare and Phillyrea latifolia to high solar radiation. New Phytologist. 2005;167(2):457-70.
53. Monibas R, Johnson AM, Osborn O, Traves PG, Mahata SK. Distinct hepatic macrophage populations in lean and obese mice. Front Endocrinol. 2016;7:152.

54. Lee IS, Kim KH, Kim J, Park HS, Jeong Y, Kim YC, et al. Anti-diabetic and anti-obesity effects of aqueous extracts of Yangkyuksanhwa-tang and its two major compositions on db/db mice. Biomed Pharmacother. 2016;83:431-8.

55. Kurup SB, Mini S. Averrhoa bilimbi fruits attenuate hyperglycemia-mediated oxidative stress in streptozotocin-induced diabetic rats. J Food Drug Anal. 2017;25(2):360-8.

56. Soliman MM, Nassan MA, Ismail TA. Origanum majoranum extract modulates gene expression, hepatic and renal changes in a rat model of Type 2 Diabetes. Iran J Pharm Res. 2016;15(Suppl):45-54.

57. Hazarika AH, Kalita DC, Boruah MC, Devi R. Pathophysiology of metabolic syndrome: The onset of natural recovery on withdrawal of a high-carbohydrate, high-fat diet. Nutrition. 2016;32(10):1081-91.

58. Sirovina DN, Orsolic MZ, Koncic A, Gregorovic G. Naringenin ameliorates pathological changes in liver and kidney of diabetic mice: A preliminary study. J Ind Hyg Toxicol. 2016;67(1):19-24.

59. Abdelaziz DHA, Ali SA. The protective effect of Phoenix dactylifera L. seeds against $\mathrm{CCl} 4$-induced hepatotoxicity in rats. J Ethnopharmacol. 2014;155(1):736-43.

60. Gupta G, Krishna G, Chellappan KS, Gubbiyappa M, Candasamy M, Dua K. Protective effect of pioglitazone, a PPAR gamma agonist against acetaminophen-induced hepatotoxicity in rats. Mol Cell Biochem. 2014;393(1):223-8.

61. Sipal S, Halici Z, Kiki I, Polat B, Albayrak A, Albayrak F, et al. Comparative study of three angiotensin II type 1 receptor antagonists in preventing liver fibrosis in diabetic rats: Stereology, histopathology and electron microscopy. J Mol Histol. 2012;43(6):723-35.

62. Bansal P, Paul P, Mudgal J, Nayak PG, Pannakal ST, Priyadarsini KI, et al. Antidiabetic, antihyperlipidemic and antioxidant effects of the flavonoid rich fraction of Pilea microphylla (L.) in high-fat diet/streptozotocin-induced diabetes in mice. Exp Toxicol Pathol. 2012;64(6):651-8.

63. Iskender H, Dokumacioglu E, Sen TM, Ince I, Kanbay Y, Saral S. The effect of hesperidin and quercetin on oxidative stress, NF-kappa B and SIRT1 levels in a STZ-induced experimental diabetes model. Biomed Pharmacother. 2017;90:500-8.

64. Almogbel E, Rasheed N. Protein mediated oxidative stress in patients with diabetes and its associated neuropathy: Correlation with protein carbonylation and disease activity markers. J Clin Diagn Res. 2017;11(2):BC21-5.

65. Ganjifrockwala FA, Joseph JT, George G. Decreased total antioxidant levels and increased oxidative stress in South African type 2 diabetes mellitus patients. J Endocrinol Metabolism Diabetes of South Africa. 2017;22(2):21-5.

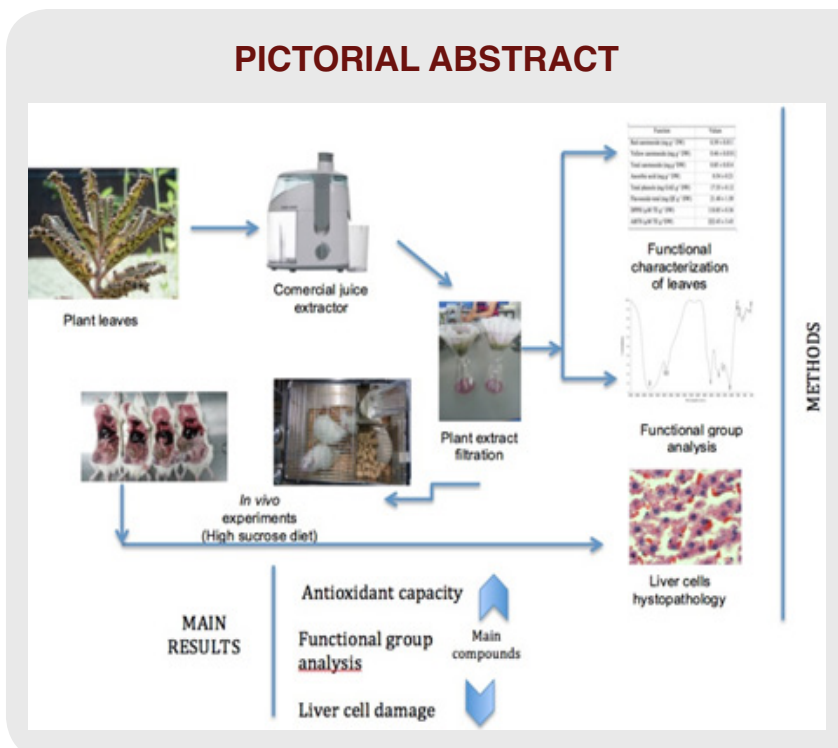

\section{SUMMARY}

Process for the Kalanchoe daigremontiana test against hyperglycemia. Extraction of sap from mature plants. Obtention of functional characteristics. Induction of hyperglycemia in laboratory animals. Feeding rats with pure extract in hyperglycemic rats. Histopathological comparison of healthy / damaged livers. Improvement of damaged livers supplied with Kalanchoe daigremontiana sap compared to controls. 


\begin{abstract}
About Authors

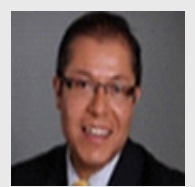

Dr. Alfredo Madariaga-Navarrete, Researcher professor of the academic program of Engineering in Agronomy for Sustainable Production of the Institute of Agricultural Sciences of the Autonomous University of the State of Hidalgo in Mexico (UAEH), where he carries out research in bioremediation of contaminated soils, as well as the generation of biological drugs.

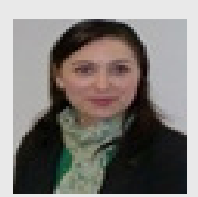

Dr. Eliazar Aquino-Torres, Professor in the Academic Area of Agricultural and Forest Sciences, Institute of Agricultural Sciences, Autonomous University of the State of Hidalgo. Tulancingo, Hidalgo, MEXICO. Her areas of research include plants extracts and secondary metabolites analysis, extraction, chemical characterization and biological activity evaluation.

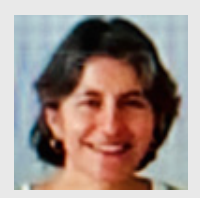

Dr. Raquel Cariño-Cortés, She has published several JCR articles on the effects of bioactive compounds with possible chemo preventive and anti-inflammatory effects at the preclinical level.

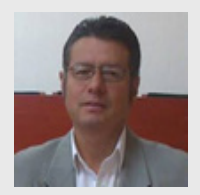

Dr. Roberto Villagómez-lbarra, He is currently dedicated to the study of the effects of plant metabolites as well as the synthesis of organic molecules in pharmaceutical and bioremediation products.

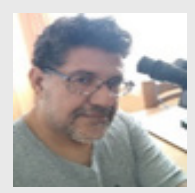

Dr. Juan Ocampo-López, Currently conducts research in the area of cell biology, veterinary morphology, molecular pathological diagnosis and methods for the prevention of diseases in domestic animals, as well as in the development of technologies for the better use of animal and plant origin products.

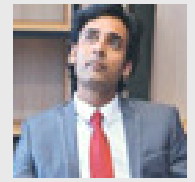

Dr. Ashutosh Sharma, Currently works as the Director of the Regional Bioengineering Department, South-Central region at the Tecnologico de Monterrey. México. He has authored more than 75 scientific contributions, including JCR indexed articles, patents, books chapters, books and conference papers. Dr. Sharma has also developed commercially successful technologies and products in the agrobiotechnology and phytomedicine field.

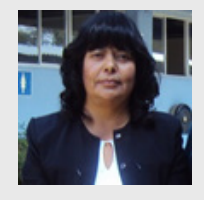

Dr. Alma Delia Hernández-Fuentes, Professor in the Academic Area of Food Engineering and Agroindustrial Engineering, Institute of Agricultural Sciences, Autonomous University of the State of Hidalgo, Mexico. Her research areas are the application of bioprocesses to agro-industrial systems and Application of phytochemicals and nutraceuticals products in agro-food systems.
\end{abstract}

Cite this article: Madariaga NA, Aquino TE, Cariño CR, Villagómez IR, Ocampo LJ, Sharma A, Hernández FAD. Kalanchoe daigremontiena: Functional properties and histopathological effects on wistar rats under Hyperglycemiainducing diet. Indian J of Pharmaceutical Education and Research. 2021;55(2):445-54. 